Article

GIANCOTTI, P.R.F. ${ }^{*}$

MORO, M.S. ${ }^{1}$

NEPOMUCENO, M.P. ${ }^{1}$

BARROSO, A.A.M. ${ }^{1}$

MARTINS, P.F.R.B. ${ }^{1}$

ALVES, P.L.C.A. ${ }^{1}$

\section{WEED COMMUNity INTERFERENCE AND Phytosociological Studies in a Sweet Sorghum Crop}

\section{Interferência e Estudos Fitossociológicos da Comunidade Infestante na Cultura do Sorgo Sacarino}

\begin{abstract}
This research was carried out to evaluate the interference periods and phytosociological indexes of the weed community on sweet sorghum, hybrid CVSW 80007 , cultivated for two seasons in a year. The treatments were based on an increased duration of weed presence and weed absence after sowing $(0,4,7,14,21,28,35,42$, 56 and 68 days after crop emergence for the summer season and $0,4,7,14,21,28,35$, $42,49,56,63$ and 100 days for the fall season). The weed community was evaluated based on the number of weeds and the dry mass of each weed population in each period of weed control in the summer season and each period of no weed control and weed control in the autumn season. These data were used to determine the relative indexes of density, dominance and importance, and the weed community indexes of diversity and equitability. The main weeds comprising the community were Cyperus rotundus, Alternanthera tenella, Indigofera hirsuta, Amaranthus sp., Digitaria nuda, and Portulaca oleracea. The weed density was found to be the primary factor for the importance of weeds in the community, once their development and biomass accumulation were suppressed by the sweet sorghum competition. The sweet sorghum hybrid proved highly competitive and, in the agro-ecological conditions of the trials, weed interference did not reduce crop yield.
\end{abstract}

Keywords: Sorghum bicolor, weeds, weed competition.

RESUMO - Este estudo teve por objetivo determinar os periodos de interferência e indices fitossociológicos da comunidade infestante da cultura do sorgo-sacarino, híbrido CVSW 80007, cultivado em duas épocas do ano. Os tratamentos consistiram de periodos crescentes de presença ou ausência da comunidade infestante (0, 4, 7, $14,21,28,35,42,56$ e 68 dias após a emergência da cultura na safra de verão e 0 , $4,7,14,21,28,35,42,49,56,63$ e 100 dias após a emergência da cultura na safra de outono). A comunidade infestante foi avaliada por meio do número de indivíduos e da massa seca de cada população de planta daninha em cada período, na presença dessas plantas na safra de verão e na presença e ausência na safra de outono. Com esses dados, foram determinados os índices de densidade, dominância e importância relativa das populações, assim como a diversidade e equitatividade da comunidade. As principais plantas daninhas encontradas foram Cyperus rotundus, Alternanthera tenella, Indigofera hirsuta, Amaranthus sp., Digitaria nuda e Portulaca oleracea. A densidade das plantas daninhas foi o fator determinante para a importância delas dentro da comunidade infestante, uma vez que o desenvolvimento e acúmulo de biomassa foram suprimidos pela competição estabelecida pelo sorgo-sacarino. O híbrido de sorgo-sacarino mostrou-se altamente competitivo; nas condições agroecológicas dos experimentos, a interferência exercida pelas populações de plantas daninhas presentes não acarretou redução da produtividade da cultura.

Palavras-chave: Sorghum bicolor, plantas daninhas, matocompetição.

1 Universidade Estadual Paulista “Júlio de Mesquita Filho”, (UNESP), Jaboticabal-SP, Brasil. 


\section{INTRODUCTION}

Ethanol mills have been recently considering sweet sorghum (Sorghum bicolor) for ethanol production because it is a real and practical alternative to reduce the period when the industry is inoperative, with no harvests. Its advantages are a short crop cycle, inexpensive equipment requirements and a high content of fermentable sugars in its stalk (Cunha and Severo Filho, 2010).

Weed interference is a factor that can affect the development and yield of sweet sorghum. Weeds can cause a lower yield by competing for limited resources (light, nutrients and water), damaging the harvest, hosting pests and diseases or using allelopathy (Pitelli, 1985). Growing a crop with no weed control can cause huge yield losses; for example, a 70\% loss of yield for grain sorghum has been reported (Silva et al., 1998) and a 54\% loss has been reported for forage sorghum (Khare et al., 1986). Little information is available about weed interference in sweet sorghum.

The study of weeds in agroecosystems has indicated so called critical periods for weed control, which can provide a logical basis for the development of an integrated weed management system for a particular crop. The critical timing of weed removal (CTWR), the critical weed-free period (CWFP) and the critical period of weed control (CPWC) have been defined in previous studies (Pitelli and Durigan, 1984; Knezevic et al., 2002). The CPWC encompasses growth stages at which the crop is more vulnerable to weed competition, in other words, the period in which the crop has to be kept free from weeds to prevent significant yield losses (Kavaliauskaite and Bobinas, 2006; Carvalho et al., 2008).

Phytosociological studies are tools for weed monitoring that have been used to understand the weed community and the role of each population in an agroecosystem (Braun-Blanquet, 1979). Such studies allow several inferences about a weed in each ecological case by providing specific parameters about a weed in the population, such as its frequency, density, dominancy and the importance of that particular weed in relation to the overall weed community (Erasmo et al., 2004; Adegas et al., 2010).

Since the adoption of sweet sorghum crop is recent and still in commercial development, there is a lack of current scientific information about the weed interference for this specific type of sorghum. Moreover, due to the specific characteristics of sweet sorghum, the interference periods for this crop can differ from those reported for grain sorghum or forage sorghum. The aim of this study was to determine the critical periods for weed control in sweet sorghum and to determine the phytosociological indexes of the weed community of sweet sorghum in the northern region of São Paulo State.

\section{MATERIALS AND METHODS}

\section{Site description, soil preparation and sowing}

This study comprised two field trials carried out sequentially in the city of Jaboticabal, São Paulo State, at the coordinates $21^{\circ} 15^{\prime} 17^{\prime \prime} \mathrm{S}, 48^{\circ} 19^{\prime} 20^{\prime \prime} \mathrm{W}$, at a $590 \mathrm{~m}$ altitude. The soil was classified as a very clayey textured eutrophic Red Latosol (ERL), and chemical analysis of the soil showed a $\mathrm{pH}\left(\mathrm{CaCl}_{2}\right)$ of 5.7, an $\mathrm{OM}$ of $40 \mathrm{~g} \mathrm{dm}^{-3}$, a P concentration of $73 \mathrm{mg} \mathrm{dm}^{-3}$; and 3.8, 45, 18 and $23 \mathrm{mmol}_{\mathrm{c}} \mathrm{dm}^{-3}$ of $\mathrm{K}, \mathrm{Ca}, \mathrm{Mg}$ and $\mathrm{H}+\mathrm{Al}$, respectively. Sweet sorghum was sown on December $5^{\text {th }}, 2012$ (summer trial) and March 4th 2013 (fall trial), using fertilization as recommended (Raij et al., 1997) for forage sorghum. Half as much fertilizer was used in the fall trial to avoid crop lodging.

The sweet sorghum hybrid CVSW 80007 was used in both field trials. The row spacing for the summer trial was $0.80 \mathrm{~m}$, with 13 seeds in each meter of a row, and the row spacing was $0.90 \mathrm{~m}$ for the fall trial, with 8 seeds in each meter of a row. The seedlings emerged six days after sowing. The crop was fertilized with nitrogen at $110 \mathrm{~kg} \mathrm{ha}^{-1}$ of 36-00-12 NPK fertilizer 20 days after seedling emergence. 


\section{Experimental design and treatments}

Two groups of treatments were established after sowing: one group consisted of crescent periods of no weed control, while the other consisted of crescent periods of weed control. Hoeing was used to keep the plots weed free. The periods were $0,4,7,14,21,28,35,42,56$ and 68 days after emergence (DAE) for the summer trial, and $0,4,7,14,21,28,35,42,49,56,63$ and $100 \mathrm{DAE}$, for the fall trial, for each group of treatments.

The treatments were spread in the plots in a randomized block design with four repetitions. Each plot was composed of 4 crop rows $8 \mathrm{~m}$ long for the summer trial and $6 \mathrm{~m}$ long for the fall trial.

\section{Determination of the phytosociological indexes}

The phytosociological indexes were determined during the crescent weedy periods for both trials. The weed community was sampled in each plot from two $0.25 \mathrm{~m}^{2}$ quadrants, randomly selected in the plot area. The aboveground weeds were collected, separated by species, dried to a constant weight in a forced-air convection oven at $65 \pm 2{ }^{\circ} \mathrm{C}$ and weighed on a precision scale. The species identification was based on the classification system of the Angiosperm Phylogeny Group - APG III (2009).

The phytosociological parameter known as the relative importance index (RIm) was determined, which requires three other parameters for its determination, as follows: the relative constancy (RCo), relative density (RDe) and relative dominancy (RDo). Our analysis followed Carvalho et al. (2008). RCo represents the reoccurrence of a species at different sites in a community. RDe is estimated by recording the number of individuals of a population in relation to the total number of individuals in the community. RDo represents the percentage of dry mass accumulated by a species in relation to the dry mass of the total weed community.

The indexes of diversity ( $\left.\mathrm{H}^{\prime}\right)$ and equitability (E') proposed by Shannon-Weaver (Carvalho et al., 2008) were also determined. The equitability index is the ratio of $\mathrm{H}^{\prime}$ in a certain community to the theoretical maximum of H', which occurs when the populations equally share a particular feature (Pinto-Coelho, 2000). H' and E' were calculated based on RDe, RDo and RIm.

\section{Crop measurements and data analyses}

In the summer trial, the sorghum plants showed vigorous growth, causing crop lodging at 68 DAE. On the same day, the sorghum plants from the central meter of each plot were collected and dried to constant weight to determine the dry mass (g per plant and ton ha ${ }^{-1}$ ). In the fall trial, the crop was harvested at $100 \mathrm{DAE}$, and the sweet sorghum yield of each plot was determined by weighting the stalks from the two central meters of the two central rows ( $4 \mathrm{~m}$ total). The weight was measured immediately with a weight scale with a $20 \mathrm{~g}$ accuracy. The fresh mass (ton ha-1 and g per plant), plant height (in meters from ground to the last expanded leaf or the flag leaf) and stalk diameter (in $\mathrm{mm}$ at $5 \mathrm{~cm}$ from the ground) were determined. During the harvest, the Brix level (\%) of the treatment extremes (i.e., the entire period with or without weed control) was determined.

The data were analyzed using ANOVA and Tukey's test at 5\% probability, with Assistat v.7.6 beta software.

\section{RESULTS AND DISCUSSION}

\section{Summer field trial}

During periods of no weed control in the summer field trial, 19 species of weeds, belonging to 11 families were found infesting the crop (Table 1). At $68 \mathrm{DAE}$, the weeds with the greatest density and biomass accumulation were Cyperus rotundus and Commelina benghalensis.

No weeds were found at 4 DAE. During the other periods, C. rotundus had the highest RIm index, followed by Digitaria nuda and Amaranthus spp. (Figure 1). However, the RIm of the sum of 
the other less important species was higher than the indexes of the important species in all periods evaluated, reflecting the weed diversity in the field (Figure 1).

Table 1 - Scientific names and families of the weeds present during all the phytosociological surveys and their density and dry mass at 68 DAE in the sweet sorghum hybrid CVSW 80007 grown during the summer, in the treatment without weed control

\begin{tabular}{|c|c|c|c|}
\hline Family & Binomial name & $\begin{array}{c}\text { Density } \\
\text { (plants } \mathrm{m}^{-2} \text { ) }\end{array}$ & $\begin{array}{c}\text { Dry mass } \\
\left(\mathrm{g} \mathrm{m}^{-2}\right)\end{array}$ \\
\hline \multirow{2}{*}{ Amaranthaceae } & Alternanthera tenella Colla & 3.50 & 2.98 \\
\hline & Amaranthus spp. & 8.00 & 2.84 \\
\hline \multirow{3}{*}{ Asteraceae } & Acanthospermum hispidum & 0.50 & 0.83 \\
\hline & Parthenium hysterophorus L. & 1.00 & 0.46 \\
\hline & Xanthium strumarium L. & $-*$ & - \\
\hline Brassicaceae & Raphanus raphanistrum L. & 0.50 & 0.00 \\
\hline Commelinaceae & Commelina benghalensis L. & 3.00 & 9.12 \\
\hline \multirow{5}{*}{ Convolvulaceae } & Ipomoea hederifolia $\mathrm{L}$. & - & - \\
\hline & Ipomoea nil (L.) Roth & - & - \\
\hline & Ipomoea purpurea (L.) Roth & 0.50 & 0.03 \\
\hline & Ipomoea quamoclit $\mathrm{L}$. & - & - \\
\hline & Merremia aegyptia L. & 0.50 & 3.08 \\
\hline Cyperaceae & Cyperus rotundus $L$. & 12.00 & 5.72 \\
\hline Fabaceae & Indigofera hirsuta $\mathrm{L}$. & - & - \\
\hline Malvaceae & Sida rhombifolia L. & - & - \\
\hline Phyllanthaceae & Phyllanthus tenellus Roxb. & - & - \\
\hline \multirow{3}{*}{ Poaceae } & Digitaria nuda (Schumach.) & 7.00 & 2.96 \\
\hline & Eleusine indica (L.) Gaertn. & 2.00 & 0.45 \\
\hline & Panicum maximum (Jacq.) B.K. Simon \& S.W.L. Jacobs & 1.50 & 0.31 \\
\hline Portulacaceae & Portulaca oleracea $\mathrm{L}$. & - & \\
\hline
\end{tabular}

* Weed species not sampled during the weed community evaluation in the treatment without weed control until the end of the field trial.

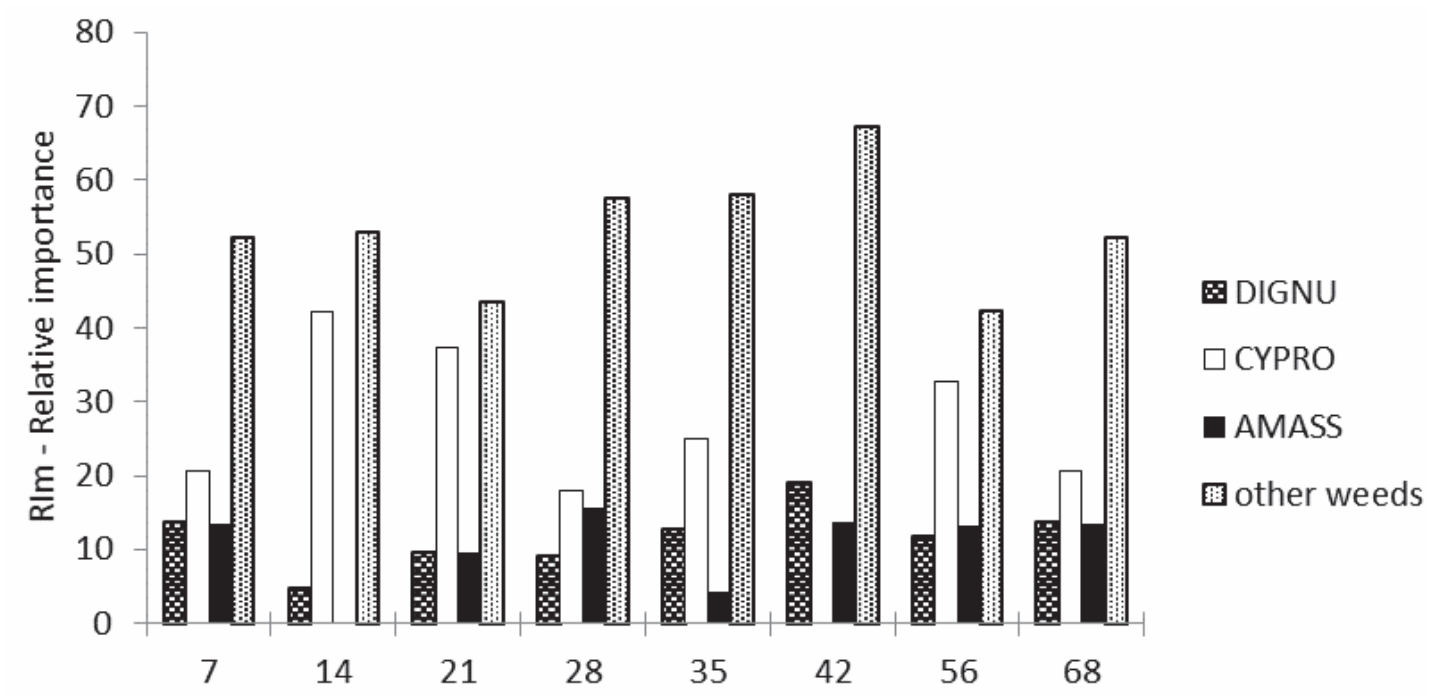

Periods with no weed control - in days after the crop emergence

DIGNU = Digitaria nuda $;$ CYPRO = Cyperus rotundus; AMASS $=$ Amaranthus $s p$.

Figure 1 - Relative importance index (RIm) of the primary weed populations in sweet sorghum, hybrid CVSW 80007, grown during the summer, during periods with no weed control. 
C. rotundus is competitive during the entire crop cycle and, according to Arévalo et al. (1996), the most critical period occurs during the initial development of the crop. This weed had the highest RIm index in the trial, even for longer periods of no weed control (Figure 1).

The diversity index of the community that considered the relative importance of the populations ( $\left.\mathrm{H}^{\prime} \mathrm{RIm}\right)$ was similar to the diversity index that considered the relative density $\left(\mathrm{H}^{\prime}\right.$ $\mathrm{RDe}$ ), so the RIm was more greatly affected by the number of individuals than the accumulation of biomass (Figure 2A). After 7, 14 and 21 days of no weed control, the equitability index that considered the relative dominance ( $E^{\prime} \mathrm{RDo}$ ) was lower than 0.5. In other words, the biomass accumulation of the weed community was restricted during these periods by a limited number of weed species (Figure 2B). The low values of H' RDo and E' RDo were due the prevalence of C. rotundus in the weed community (Figures 1 and 2).

During periods of no weed control, less variation of E' was found for RDe and RIm, compared to RDo. The differences were more pronounced during the first periods of no weed control, but almost completely absent at the end of the crop cycle (Figure 2B).

The aboveground dry mass of sweet sorghum did not differ when the crop was subjected to crescent periods of weed control or no weed control and had an average of 14.8 ton ha ${ }^{-1}$ and 90.9 g per plant (Table 2).

In a field trial, Kuva et al. (2000) did not find a lower yield of sugarcane due to C. rotundus when the weed was controlled only until 22 days after the crop was planted. In the present study,
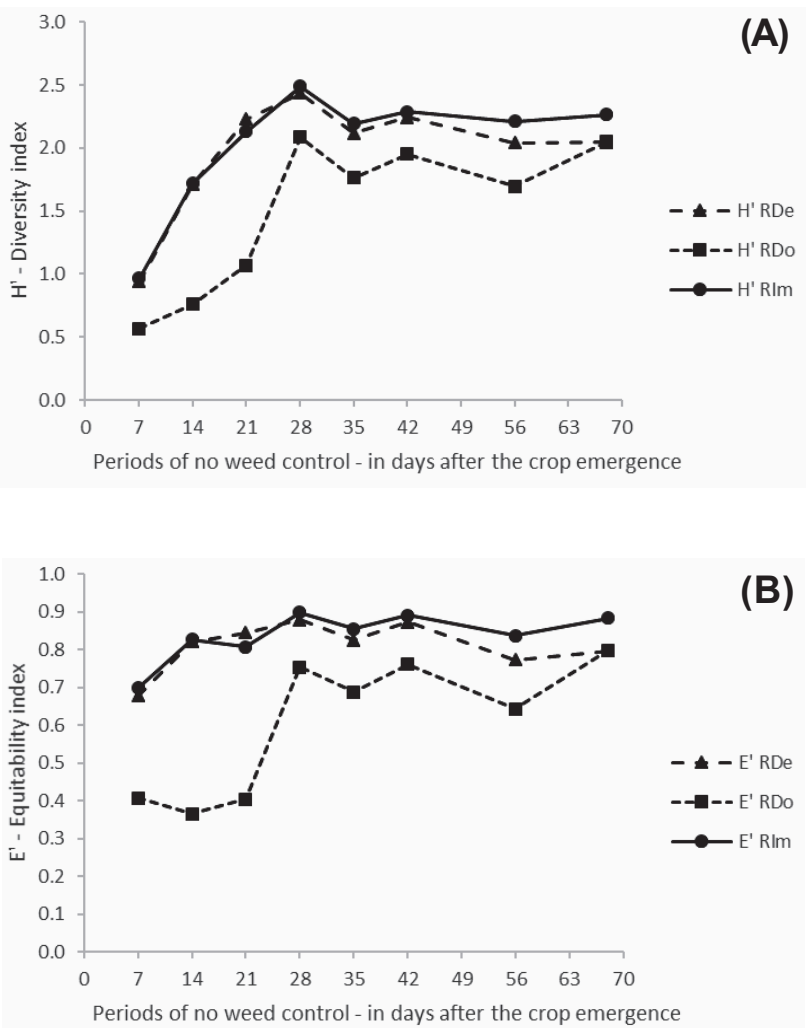

The relative density (RDe), relative dominancy (RDo) and relative importance (RIm) were used to determine $\mathrm{H}^{\prime}$ and $\mathrm{E}^{\prime}$.

Figure 2 - Diversity (H') (A) and equitability (E') (B) indexes of the weed community infesting sweet sorghum hybrid CVSW 80007, grown during the summer over the increasing periods with no weed control.
Table 2 - Dry mass of the sweet sorghum hybrid CVSW 80007 over increasing periods of weed control and no weed control, at $68 \mathrm{DAE}$ for the summer crop

\begin{tabular}{|c|c|c|}
\hline \multirow{2}{*}{$\begin{array}{c}\text { DAE - Days after } \\
\text { emergence }\end{array}$} & \multicolumn{2}{|c|}{ Dry mass } \\
\hline & (g per plant) & $\left(\right.$ ton $\left.\mathrm{ha}^{-1}\right)$ \\
\hline \multicolumn{3}{|c|}{ Crop maintained with no weed control } \\
\hline 0 & 87.06 & 15.28 \\
\hline 4 & 87.42 & 15.53 \\
\hline 7 & 96.35 & 15.33 \\
\hline 14 & 101.44 & 15.78 \\
\hline 21 & 85.11 & 12.89 \\
\hline 28 & 90.36 & 13.73 \\
\hline 35 & 107.96 & 13.95 \\
\hline 42 & 89.16 & 14.95 \\
\hline 56 & 85.34 & 12.85 \\
\hline 68 & 95.37 & 15.76 \\
\hline $\mathrm{F}$ & $0.89^{\mathrm{NS}}$ & $1.20^{\mathrm{NS}}$ \\
\hline $\mathrm{VC}(\%)$ & 18.57 & 14.35 \\
\hline \multicolumn{3}{|c|}{ Crop maintained with weed control } \\
\hline 0 & 97.58 & 15.54 \\
\hline 4 & 82.50 & 15.20 \\
\hline 7 & 100.33 & 16.91 \\
\hline 14 & 77.20 & 13.65 \\
\hline 21 & 84.69 & 14.23 \\
\hline 28 & 98.11 & 14.83 \\
\hline 35 & 83.53 & 14.82 \\
\hline 42 & 94.57 & 13.89 \\
\hline 56 & 84.47 & 15.13 \\
\hline 68 & 90.19 & 15.15 \\
\hline $\mathrm{F}$ & $1.56^{\mathrm{NS}}$ & $0.34^{\mathrm{NS}}$ \\
\hline VC $(\%)$ & 18.73 & 21.29 \\
\hline
\end{tabular}

Ns Not significant by Tukey's test ( $\mathrm{p}>0.05)$. 
C. rotundus was the most important weed although it did not affect the sweet sorghum dry mass. These results suggest that the weed interferes less with the yield of robust crops, such as sweet sorghum and sugarcane, in advanced stages.

\section{Fall field trial}

During periods of weed control and no weed control, 22 species of weeds from 12 families were sampled and identified (Table 3). Alternanthera tenella was the weed with the highest density $\left(15\right.$ plants $\left.\mathrm{m}^{-2}\right)$ and dry mass $\left(33 \mathrm{~g} \mathrm{~m}^{-2}\right)$ at harvest in plots with no weed control since emergence (Table 3).

No weeds in the sampled area at the first phytosociological evaluation were found at 4 DAE. During periods of no weed control in the crop, the A. tenella, P. oleracea, and I. hirsuta populations had the highest RIm values in that order (Figure 3A). During the first evaluations (i.e., 7, 14 and 21 days of no weed control), the weeds with the highest RIm indexes were I. hirsuta and P. oleracea. From 28 days onward, A. tenella had the highest RIm index in the weed community (Figure 3A).

During periods of weed control in the fall, the species with the highest RIm index was A. tenella, followed by I. hirsuta and C. benghalensis (Figure 3B). During the intermediated periods of weed control $(28,35,42$ and $49 \mathrm{DAE})$, the RIm index of $A$. tenella decreased and, consequently, the three most important weeds had values of RIm that were less different with respect to each other (Figure 3B).

Alternanthera tenella is an important weed in agriculture, due to its rapid dissemination and high density of infestation, especially in the Cerrado ecoregion (Canossa et al., 2008). It is considered a species that emerges late during the summer, and usually does not interfere in

Table 3 - Scientific names and families of the weeds present during all the phytosociological surveys and their density and dry mass at 68 DAE in the sweet sorghum hybrid CVSW 80007 grown during the fall, in the treatment without weed control

\begin{tabular}{|c|c|c|c|}
\hline Family & Binomial name & $\begin{array}{c}\text { Density } \\
\left(\text { plants } \mathrm{m}^{-2}\right)\end{array}$ & $\begin{array}{c}\text { Dry mass } \\
\left(\mathrm{g} \mathrm{m}^{-2}\right)\end{array}$ \\
\hline \multirow{2}{*}{ Amaranthaceae } & Alternanthera tenella Colla & 15.50 & 33.00 \\
\hline & Amaranthus spp. & 2.50 & 0.04 \\
\hline \multirow{3}{*}{ Asteraceae } & Acanthospermum hispidum D.C. & $-*$ & - \\
\hline & Parthenium hysterophorus L. & - & - \\
\hline & Xanthium strumarium L. & - & - \\
\hline Commelinaceae & Commelina benghalensis L. & 3.00 & 0.42 \\
\hline \multirow{5}{*}{ Convolvulaceae } & Ipomoea nil (L.) Roth & - & - \\
\hline & Ipomoea purpurea (L.) Roth & 0.50 & 0.29 \\
\hline & Ipomoea quamoclit $\mathrm{L}$. & - & - \\
\hline & Merremia aegyptia $\mathrm{L}$. & - & - \\
\hline & Merremia cissoides (Lam.) Hall. & - & - \\
\hline Cyperaceae & Cyperus rotundus L. & - & - \\
\hline \multirow{2}{*}{ Euphorbiaceae } & Ricinus communis L. & - & - \\
\hline & Euphorbia heterophylla L. & - & - \\
\hline \multirow{2}{*}{ Fabaceae } & Indigofera hirsuta $\mathrm{L}$. & 7.50 & 14.34 \\
\hline & Mimosa pudica $\mathrm{L}$. & 0.50 & 0.01 \\
\hline Lamiaceae & Leonotis nepetifolia (L.) R.Br. & 1.00 & 0.04 \\
\hline Malvaceae & Sida rhombifolia L. & - & - \\
\hline Phyllanthaceae & Phyllanthus tenellus Roxb. & 2.00 & 0.01 \\
\hline \multirow{3}{*}{ Poaceae } & Digitaria nuda (Schumach.) & - & - \\
\hline & Eleusine indica (L.) Gaertn. & 1.00 & 0.95 \\
\hline & Cenchrus echinatus L. & 1.00 & 4.39 \\
\hline Portulacaceae & Portulaca oleracea L. & - & - \\
\hline
\end{tabular}

* Weed species not sampled during the weed community evaluation in the treatment without weed control until the end of the field trial. 

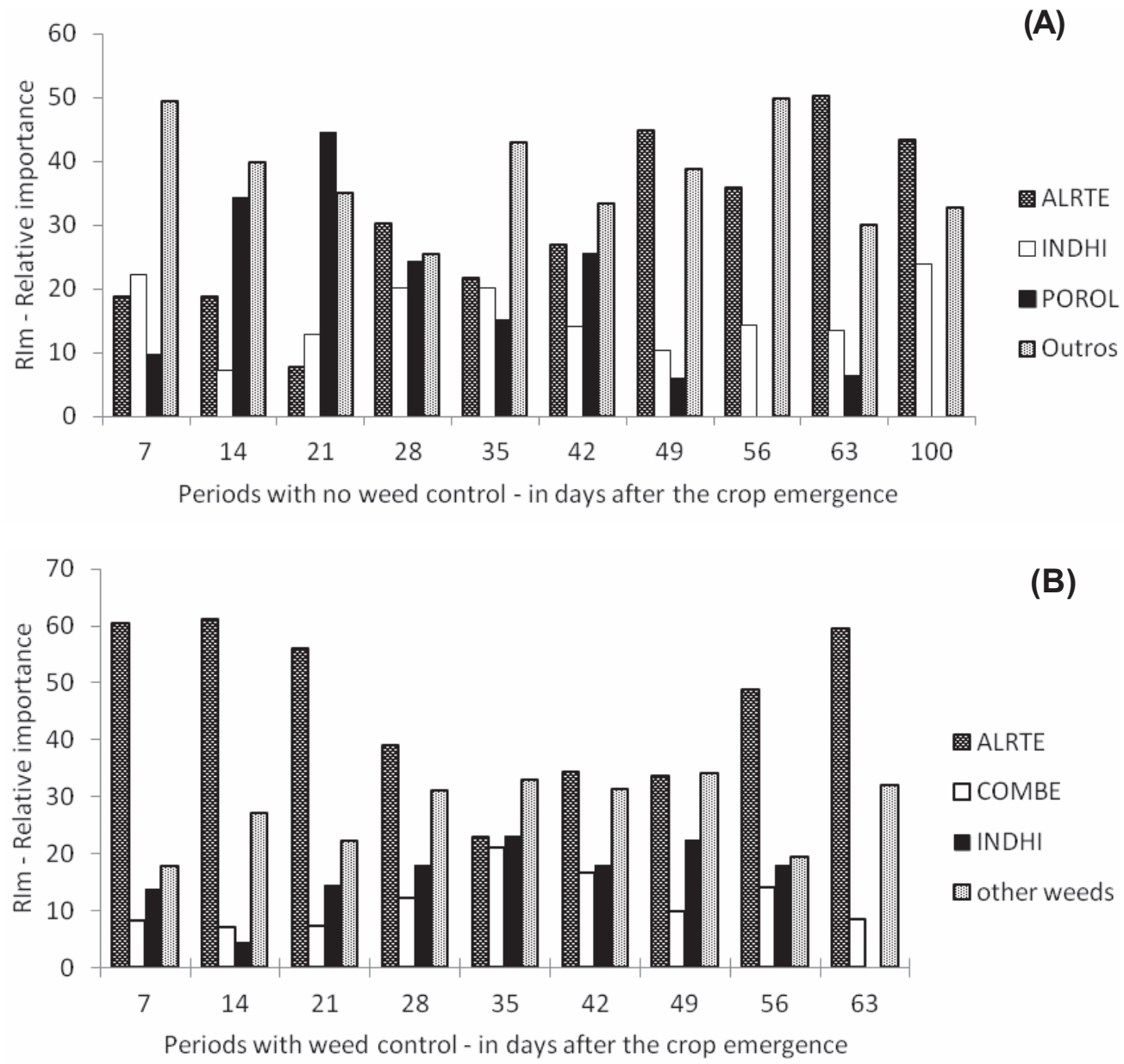

ALRTE $=$ Alternanthera tenella $; \mathrm{POROL}=$ Portulaca oleracea $; \mathrm{COMBE}=$ Commelina benghalensis $; \mathrm{INDHI}=$ Indigofera hirsuta.

Figure 3 - Relative importance index (RIm) of the primary weed populations in sweet sorghum hybrid CVSW 80007 grown during fall, during periods with no weed control (A) and with weed control (B).

the initial crop growth (Canossa et al., 2008). Such behavior was observed in this study; A. tenella did not show an excess RIm index during the summer season as in the fall, due its seasonal growth habit (Figures 1 and 3 ).

During crescent periods with no weed control and weed control, the H' and E' indexes for RDe were similar to those for RIm (Figures 4 and 5). Therefore, the population RIm values was more greatly affected by the number of individuals than the dry mass accumulation. Such weed community behavior prevailed in all periods and was more pronounced during the two higher periods of no weed control and for the three lower periods of weed control (Figures 4 and 5). In other words, a higher weed pressure had a greater effect on the weed density than it did on biomass accumulation. Hence, the weeds were smaller in size, which could have been a consequence of the competition of sweet sorghum.

The A. tenella domain in the weed community infesting the sweet sorghum reduced the H' and E' indexes for the weed control periods of 7, 14 and 21 DAE (Figures 3 and 5).

No differences in the Brix rate $\left(\mathrm{F}=0.08^{\mathrm{NS}}, \mathrm{VC}=19.24 \%\right)$ were found during the yield evaluation between the sweet sorghum stalks subjected to extreme treatments (i.e., a full cycle with weed control $[\bar{x}=15.21 \%]$ and a full cycle with no weed control $[=14.79 \%])$.

The height of the sweet sorghum did not vary during the presence or absence of weed control (Table 4). The mean of the crop height was $2.06 \mathrm{~m}$. The variable stem diameter was also similar for plants of different treatments, remaining between 14.8 and $16.1 \mathrm{~mm}$. In all treatments, the 

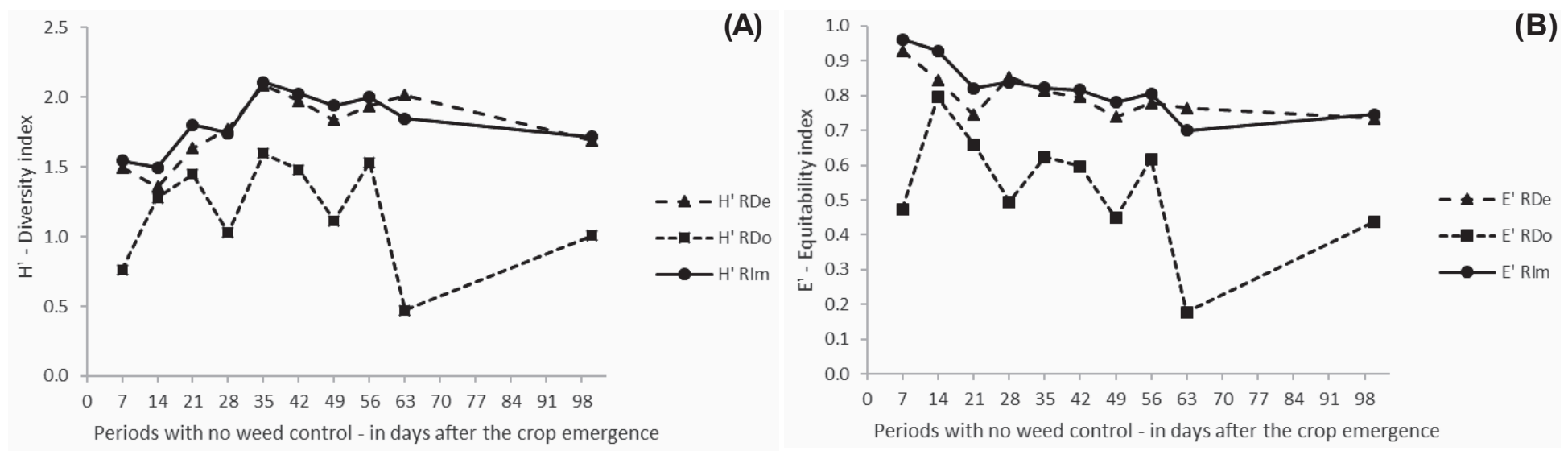

The relative density (RDe), relative dominancy (RDo) and relative importance (RIm) were used to determine H' and E'.

Figure 4 - Diversity (H') (A) and equitability (E') (B) indexes of the weed community infesting sweet sorghum, hybrid CVSW 80007, grown during the fall, over the increasing periods with no weed control.
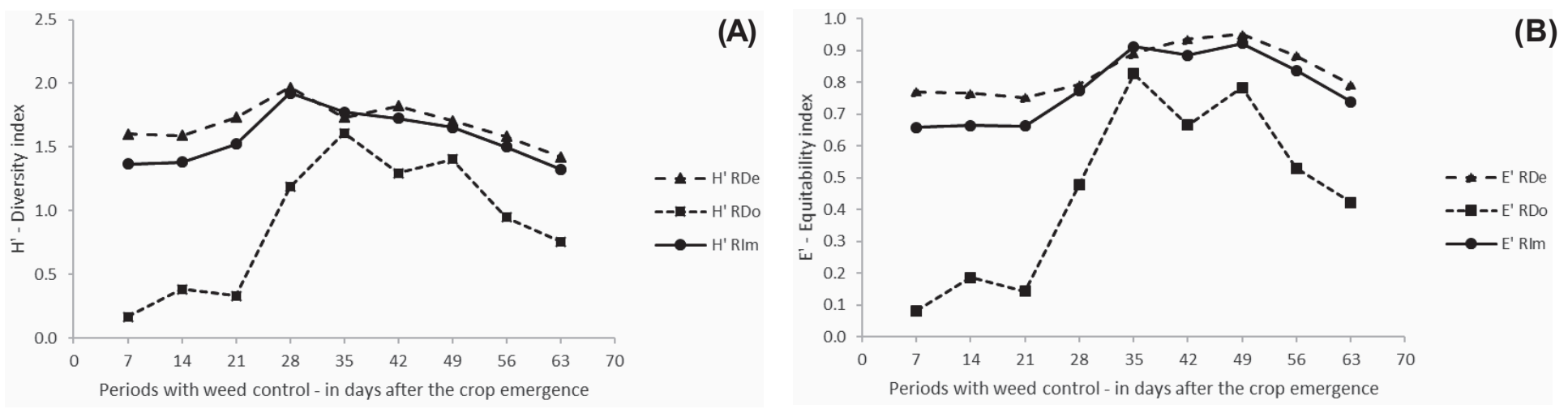

The relative density (RDe), relative dominancy (RDo) and relative importance (RIm) were used to determine H' and E'.

Figure 5 - Diversity (H') (A) and equitability (E') (B) indexes of the weed community infesting sweet sorghum hybrid CVSW 80007, grown during the fall over the increasing periods with weed control.

stem fresh mass per plant or the yield was not different. The sweet sorghum yield had an overall mean of 25.7 ton ha-1 (Table 4).

\section{Common results in both trials}

In addition to the slow initial growth of grain sorghum and its susceptibility to weed interference (Kramer and Kross, 1975), the results of the present study show the opposite for sweet sorghum, i.e., that it was extremely competitive. In the summer trial, the rapid growth and development of the sorghum even led to crop lodging, an undesirable condition. Such robust sweet sorghum vegetative development could have been the reason for the non-significant weed interference observed in both seasons.

In both field trials, the $\mathrm{H}^{\prime}$ and $\mathrm{E}^{\prime}$ indexes that considered RDe were similar to those that considered RIm, demonstrating that the RIm was more greatly affected by the number of individuals than the dry mass accumulation, probably because of the rapid and vigorous growth of the sweet sorghum that allowed strong competition against the weeds, inhibiting their biomass accumulation. 
GIANCOTTI, P.R.F. et al. Weed community interference and phytosociological sutdies in a sweet sorghum crop

Table 4 - Plant height, stalk diameter and yield (fresh mass of stalk) of the sweet sorghum hybrid CVSW 80007 over increasing periods with weed control and without weed control, at 100 DAE for the fall crop

\begin{tabular}{|c|c|c|c|c|}
\hline DAE - Days after emergence & $\begin{array}{c}\text { Plant height } \\
(\mathrm{m})\end{array}$ & $\begin{array}{c}\text { Stalk diameter } \\
(\mathrm{mm})\end{array}$ & $\begin{array}{c}\text { Stalk fresh mass } \\
\text { (g per plant) }\end{array}$ & $\begin{array}{c}\text { Yield } \\
\left(\text { ton ha }{ }^{-1}\right)\end{array}$ \\
\hline \multicolumn{5}{|c|}{ Crops maintained with no weed control } \\
\hline 0 & 2.17 & 15.55 & 293.62 & 22.60 \\
\hline 4 & 2.10 & 15.91 & 304.50 & 25.31 \\
\hline 7 & 2.01 & 15.65 & 297.35 & 24.65 \\
\hline 14 & 2.05 & 15.31 & 284.02 & 25.12 \\
\hline 21 & 2.07 & 16.04 & 299.17 & 24.73 \\
\hline 28 & 2.01 & 15.09 & 285.07 & 24.35 \\
\hline 35 & 2.10 & 15.83 & 276.75 & 21.84 \\
\hline 42 & 2.03 & 15.92 & 298.83 & 26.21 \\
\hline 56 & 2.08 & 14.84 & 285.68 & 25.43 \\
\hline 63 & 2.06 & 15.51 & 278.31 & 25.87 \\
\hline 100 & 2.05 & 15.17 & 288.08 & 24.46 \\
\hline F & $1.24^{\mathrm{NS}-}$ & $0.54^{\mathrm{NS}}$ & $1.25^{\mathrm{NS}}$ & $0.31^{\mathrm{NS}}$ \\
\hline $\mathrm{VC}(\%)$ & 3.95 & 6.75 & 6.74 & 19.19 \\
\hline \multicolumn{5}{|c|}{ Crops maintained with weed control } \\
\hline 0 & 2.05 & 15.17 & 288.08 & 24.46 \\
\hline 4 & 2.04 & 15.30 & 279.88 & 26.99 \\
\hline 7 & 2.01 & 15.75 & 288.01 & 24.04 \\
\hline 14 & 2.04 & 15.29 & 284.93 & 24.85 \\
\hline 21 & 2.11 & 15.22 & 278.56 & 23.85 \\
\hline 28 & 2.01 & 15.30 & 266.80 & 24.38 \\
\hline 35 & 2.03 & 16.02 & 295.07 & 25.63 \\
\hline 42 & 2.05 & 16.09 & 291.46 & 24.95 \\
\hline 56 & 2.05 & 15.08 & 272.69 & 26.03 \\
\hline 63 & 2.03 & 15.54 & 288.56 & 24.58 \\
\hline 100 & 2.17 & 15.55 & 293.62 & 22.60 \\
\hline $\mathrm{F}$ & $1.30^{\mathrm{NS}}$ & $0.56^{\mathrm{NS}}$ & $1.81^{\mathrm{NS}}$ & $0.32^{\mathrm{NS}}$ \\
\hline $\mathrm{VC}(\%)$ & 3.97 & 5.91 & 6.40 & 16.81 \\
\hline
\end{tabular}

Ns Not significant by Tukey's test ( $\mathrm{p}>0.05)$.

The presence of weeds did not decrease the development and yield of sweet sorghum, which differs from the results of Khare et al. (1986) and Burnside (1977), who reported that the presence of weeds could cause up to a 50\% reduction in the yield of forage sorghum and grain sorghum.

Rodrigues et al. (2010) and Burnside (1977) studied the weed interference periods for a grain sorghum crop and found a CWFP of four weeks. However, it was not possible to determine the critical periods of weed control in this study. The sweet sorghum hybrid CVSW 80007 was so competitive during both summer and fall that weed interference did not reduce the crop yield.

Under the agroecological conditions of the field trials, the sweet sorghum hybrid CVSW 80007 was able to grow in the presence of weeds, after soil preparation, with no interference from weeds in the presence of a weed community mainly composed of Cyperus rotundus (with a density of 12 plants $\mathrm{m}^{-2}$ and a biomass of $5.7 \mathrm{~g}$ at 68 days after sorghum emergence) or Alternanthera tenella (with a density of 15.5 plants $\mathrm{m}^{-2}$ and a biomass of $33 \mathrm{~g} \mathrm{~m}^{-2}$ at 100 days after emergence).

\section{ACKNOWLEDGMENTS}

The authors are grateful to Capes (Coordenação de Aperfeiçoamento de Pessoal de Nivel Superior) and FAPESP (Fundação de Apoio à Pesquisa do Estado de São Paulo) for granting scholarships. 


\section{REFERÊNCIAS}

Adegas F.S. et al. Levantamento fitossociológico de plantas daninhas na cultura do girassol. Planta Daninha. 2010;28:705-16.

Andres A. et al. Períodos de interferência de plantas daninhas na cultura do sorgo forrageiro em terras baixas. Planta Daninha, 2009;27:229-234.

Arévalo, R.A. Recentes avanços em controle químico em controle químico de Cyperus rotundus (tiririca) em Saccharum spp (canade-açúcar). In: VI Congresso Nacional da Sociedade dos Técnicos Açucareiros e Alcooleiros do Brasil - STAB, Maceió, STAB, 1996. p.356- 60.

Braun-Blanquet, J. Fitossociologia: bases para el estudio de las comunidades vegetales. Madri: H. Blume, 1979. 820p.

Bremer B. et al. An update of the Angiosperm Phylogeny Group classification for the orders and families of flowering plants: APG III. Bot J Linn Soc. 2009;161:105-21.

Burnside O.C. Control of weeds in non-cultivated, narrow-row sorghum. Agron J. 1977;69:851-54.

Canossa R.S. et al. Temperatura e luz na germinação das sementes de apaga-fogo (Alternanthera tenella). Planta Daninha, 2008;26:745-50.

Carvalho L.B. et al. Interferência e estudo fitossociológico da comunidade infestante na cultura da beterraba transplantada. Acta Sci Agron. 2008;30:325-31.

Coelho J.P. et al. Efeito de antídotos na atividade das cloroacetanilidas sobre as plantas de sorgo (Sorghum bicolor (L.) Moench). Rev Ceres. 1989;36:226-40.

Cunha S.P., Severo Filho, W.A. Avanços tecnológicos na obtenção de etanol a partir de sorgo sacarino (Sorghum bicolor (L.) Moench). Tecno-Lógica. 2010;14:69-75.

Erasmo E.A.L., Pinheiro, L.L.A., Costa, N.V. Levantamento fitossociológico das comunidades de plantas infestantes em áreas de produção de arroz irrigado cultivado sob diferentes sistemas de manejo. Planta Daninha, 2004;22:195-201, 2004.

Kavaliauskaite D., Bobinas, C. Determination of weed competition critical period in red beet. Agron Res. 2006;4:217-20.

Khare P.D. et al. Nutrients uptake by forage sorghum and weeds as affected by herbicides. Indian J Weed Sci. 1986;18:231-37.

Knezevic S.Z., Evans S.P., Mainz, M. Critical period for weed control: the concept and data analysis. Weed Sci. 2002;50:773-86.

Kramer N.W., Ross, W.M. Cultivo de sorgo granífero en Estados Unidos. In: Wall J.S. compilador. Producción y usos del sorgo. Buenos Aires: Hemisferio Sur, 1975. p.93-111.

Kuva M.A. et al. Períodos de interferência das plantas daninhas na cultura da cana-de-açúcar. I - Tiririca. Planta Daninha. 2000; 18: 241-52.

Müeller-Dombois D., Ellenberg H. Aims and methods of vegetation ecology. New York: John Wiley \& Sons, 1974. 547p.

Pinto-Coelho, R. M. Fundamentos em ecologia. Porto Alegre: Artes Médicas Sul, 2000. p.87-8.

Pitelli R.A. Interferências de plantas daninhas em culturas agrícolas. Inf Agropec. 1985;11:16-7.

Pitelli R.A., Durigan, J.C. Terminologia para períodos de controle e de convivência das plantas daninhas em culturas anuais e bianuais. In: CONGRESSO BRASILEIRO DE HERBICIDAS E PLANTAS DANINHAS, 15., 1984, Belo Horizonte. Resumos... Piracicaba: SBHED, 1984. p.37.

Raij, B. van. et al. editores. Recomendações de adubação e calagem para o Estado de São Paulo. $2^{\text {a } e d . ~ C a m p i n a s: ~ I n s t i t u t o ~}$ Agronômico/Fundação IAC, 1997. 285p. (Boletim Técnico, 100).

Rodrigues A.C.P. et al. Períodos de interferência de plantas daninhas na cultura do sorgo. Planta Daninha. 2010;28:23-31.

Silva J.B., Passini T., Viana A.C. Controle de plantas daninhas na cultura do sorgo. In: Empresa Brasileira de Pesquisa Agropecuária - Embrapa. Centro Nacional de Pesquisa Milho e Sorgo. Recomendações para o cultivo do sorgo. Sete Lagoas, 1998. p.41-4 (Circular Técnica, 1). 